\title{
異常な経過をとった恙虫病の一治験例と群馬県内での 発生状況と本症の考察
}

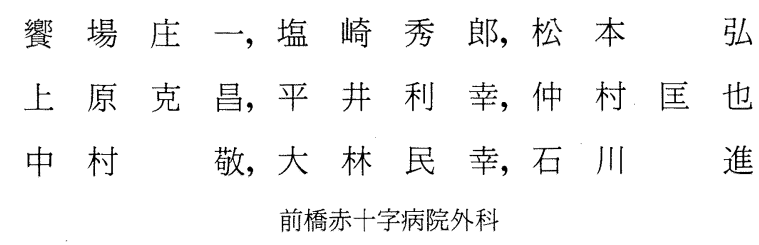

氏 家 淳 雄, 小山孝, 阿久沢 孝 文 群馬県衛生公害研究所

(昭和 59 年 8 月 1 日 受付)

\section{1 はじめに}

古来わが国には安否を気遣って“無恙乎”という 挨拶言葉があるように恙虫病は予後も悪く怖れられ ていたものと思われる。恙虫病は新潟・秋田・山形 などのごく限られた地方のみにみられた Rickettsia tsutsugamushi による急性感染症である. 対症療法 しか出来なかった戦前では 30 ～ $50 \%$ の死亡率であっ たが，テトラサイクリン・クロラムフエニコールな ぞの抗生剤の出現によって昭和 40 年から50年にかけ ては大方消滅して, 既に幻の風土病とみられていた。

ところが, 以前のものを古典的恙虫病とよべば, ここ数年来, 臨床症状・発病季節など多少異なるが 本質的には同じ恙虫病の新型とみられる疾患の流行 が，以前経験されなかった地方にまで発生して，し かも DIC などで死亡した症例まで報告されている。 今回私達は原因不明のまま急性腹症として開腹した ような異常な経過をとつた一例を治験したので文献 的考察を加えて報告する。

\section{2 症例}

33 才の女性, 既往歴には虫垂炎と 2 回の帝王切開 以外に著患がなく, 農業に従事している.

5 月 1 日頃, 両膝膝窩部辺に痒感があったがカブ レたものと思っていた。経過は図1に示したように 5 月 16 日から $38.5^{\circ} \mathrm{C}$ に発熱. 18日に発疹を生じて近 医で風疹を疑われた。22日午前 3 時頃から腹痛が出 現して紹介されて入院した。初診時には発疹・嘔気・
嘔吐・下痢などは認めない. 血圧 $110 / 76 \mathrm{mmHg}$, 脈搏 118 , 呼吸数 44 , 体温 $39.5^{\circ} \mathrm{C}$, 腹部全体に圧痛がある が明らかな筋性防禦はなく輸液とセフェム系の抗生 剤の投与で様子をみた。 24 日動脈血培養を試みたが 後日結果は陰性と報告された。

入院時検查成績を表 1 に示した. 白血球数 11,400 , 赤血球 $360 \times 10^{4}, \mathrm{Hb} 10.6 \mathrm{~g} / \mathrm{dl}$, GOT 232, GPT 207, ALP 12.1KAU, $\gamma$-GTP 95mu/ml, LDH 1,039mu/ $\mathrm{ml}$, などで白血球増加・血液像ではリンパ球減少と 好中球の核左方移動著明 - 軽度の貧血と肝機能障害 を認めた。

熱は $38.2^{\circ} \mathrm{C} \sim 40.5^{\circ} \mathrm{C}$ におよぶ弛張熱で 5 月 25 日に は白血球数は 14,500 , ASLO $12 \mathrm{u}, \mathrm{CRP}(6+)$, 腹 痛も強くとくに左下腹部に圧痛 $(+$ ), Dé $(+)$, Blumberg $(+)$ など腹部所見から原因は知れないが腹膜炎 として開腹した。脾腫と少量の腹水以外飞著変なく リムルス試験 $(+$ ) から敗血症として加療を続けた。 血液凝固機能は延長, Fibrinogen $89 \mathrm{mg} / \mathrm{dl}, \mathrm{FDP}$ $10 \mu \mathrm{g} / \mathrm{ml}$, 血小板数 10 万, $\mathrm{LDH} 1037 \mathrm{mu} / \mathrm{ml}$ などか ら DIC も考えられた. 術後 2 日目に右下腿に小豆大 の黒色の痂皮をつけた潰瘍を認めたので恙虫病も 疑ってテトラサイクリン系である Doxycycline の 併用投与を行った。一方群馬県衛生公害研究所の氏 家所長に連絡して血清検査を依頼した。

術前から心悸六進・呼吸の促迫を認めたが術後は さらに強く, 代謝性 alkalosis で術後 3 日間は Ventilator による呼吸管理と monitor の装着をし て digitalisation を行った。術後 4 日目に気管内 
图 1 M. T. 33歳女性. 恙虫病 経過

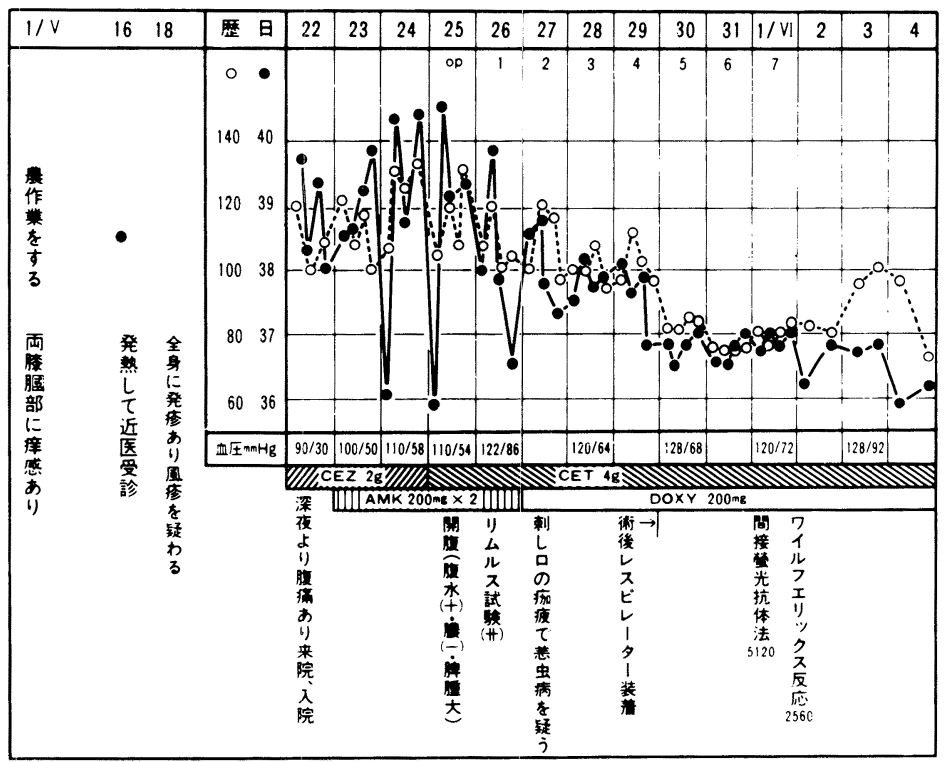

表 1 〔検査成績〕33歳, 女性

\begin{tabular}{|c|c|c|c|}
\hline \multicolumn{2}{|l|}{ 血液検査 } & \multicolumn{2}{|l|}{ 肝端能 } \\
\hline $\mathbf{R}$. & $360 \times 10^{4}$ & ZTT. & $5.4 U$ \\
\hline $\mathrm{Hb}$. & $10.6 \mathrm{~g} / \mathrm{dl}$ & TTT. & $3.9 U$ \\
\hline $\mathrm{Ht}$. & $30.6 \%$ & 総ビ & $1.1 \mathrm{ing} / \mathrm{d} \ell$ \\
\hline$w$. & 11.400 & 直ビ & $0.5 \mathrm{ing} / \mathrm{dl}$ \\
\hline \multirow{2}{*}{\multicolumn{2}{|c|}{$\begin{array}{l}\text { B: } 0, \text { E }: 0, \text { Stab: } 19, \\
\text { Seg }: 69, \text { Ly }: 10, \text { Mo: } 2 \%\end{array}$}} & GOT. & $232 \mathrm{U}$ \\
\hline & & GPT. & $207 \mathrm{U}$ \\
\hline PL. & $10 \times 10^{4}$ & ALP. & $12.1 \mathrm{KAU}$ \\
\hline \multicolumn{2}{|l|}{ 血清蛋白 } & $\gamma \cdot \mathbf{G T P}$ & $95 \mathrm{mu} / \mathrm{ml}$ \\
\hline TP. & $6.4 \mathrm{~g} / \mathrm{dl}$ & LDH. & $1037 \mathrm{mu} / \mathrm{ml}$ \\
\hline A/G. & 1.06 & TG & $250 \mathrm{mg} / \mathrm{dl}$ \\
\hline Alb. & $51.5 \%$ & \multicolumn{2}{|l|}{ 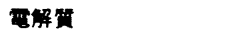 } \\
\hline$\alpha_{1}$ & 6.9 & $\mathrm{Na}$. & $137 \mathrm{mEq} / \ell$ \\
\hline$\alpha_{2}$ & 9.7 & $\mathrm{~K}$. & $4.1 \mathrm{mEq} / \ell$ \\
\hline$\beta$ & 14.5 & $\mathrm{Ca}$. & $3.8 \mathrm{mEq} / \ell$ \\
\hline y & 17.4 & $\mathrm{Cl}$. & $97 \mathrm{mEq} / \ell$ \\
\hline 総脂留 & $309 \mathrm{mg} / \mathrm{dl}$ & \multicolumn{2}{|l|}{ 雷柲能 } \\
\hline \multicolumn{2}{|c|}{$\beta$ ・リポ蛋白 $\quad 307 \mathrm{mg} / \mathrm{d} \ell$} & BUN & $14 \mathrm{mg} / \mathrm{dl}$ \\
\hline 血糖 & $130 \mathrm{mg} / \mathrm{d} \ell$ & S-尿酰 & $4.0 \mathrm{mg} / \mathrm{d} l$ \\
\hline ASLO & $120 U$ & S-creat. & $1.2 \mathrm{mg} / \mathrm{dl}$ \\
\hline CRP & $6+$ & 尿蛋白 & $(-)$ \\
\hline RAテス & $+(-)$ & 尿涺 & $(-)$ \\
\hline
\end{tabular}

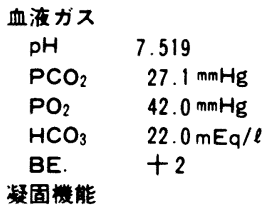

prothrombin時圆 14.0 秒

部分 Thrombopl 時间 29.7 秒

Ca.再加試駼 142.2 秒

Fibrinogen $89 \mathrm{mg} / \mathrm{d} \ell$

FDP $\quad 10 \mu \mathrm{g} / \mathrm{ml}$

間接紫光抗体法

IgG, IgM

$5120 \quad 5120$

ワィルフェリックス反応

北研慗抗原, デンカ生研製

2560

1280
チューブを抜管した。 その後は比較的容易に解熱し て一般的に経験される敗血症の経過とは異なるもの との印象であった. その後順調に経過して肝機能検 查成績も 2 週後には正常化して 6 月17日に退院し た。

血清反応ではワイルフエリックス反応は北研製抗 原で2560，デンカ生研製で1280，間接蛍光抗体法で は Karp 株を L-細胞内で増殖させたものを使用し
て IgG 5120, IgM 5120で恙虫病と認定された。6力 月後の抗体価も比較的高值を示していた。

図 2 は本症例での刺口と思われた痂皮で被われた 潰瘍を示した。

\section{3 群馬県内での恙虫病 ${ }^{1 \sim 4)}$}

群馬県内のある地方には，昔から“朝帰り熱”“朝 州り風邪”とよばれた病気があったという。野山を 
図 2

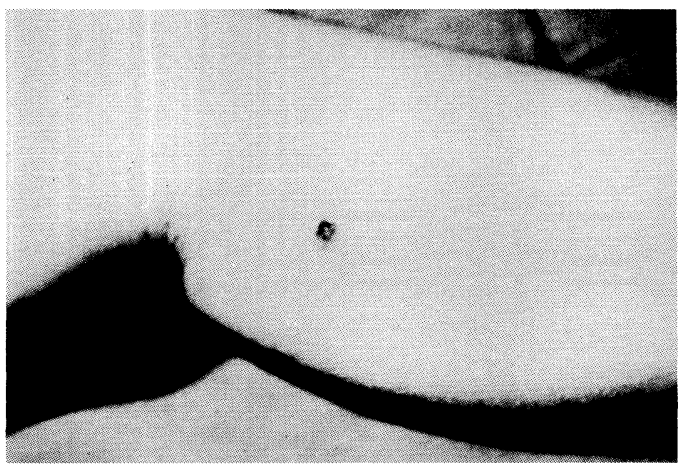

散歩したりしたあと，この熱病になるといわれてい たがどうやら恙虫病らしいということであるが定か でない. 群馬県の中之条町近郊で恙虫病らしい有熱 発疹性疾患があるということから群馬県衛生公害研 究所・中之条保健所・吾妻郡医師会などが中心となっ て検討をはじめて昭和 50 年・51年・52年の 3 年間に 18例が恙虫病の疑いをもたれた。そこで血清学的検 討の準備がはじめられて翌53年には18例の届出患者 のうち 15 例が本症と確認された。 その後昭和 54 年に 24 例，55年に 25 例，56年に20例，57年に 20 例，58年 に 6 例が報告されている.

その大部分が 10 月から 12 月の発生である。昭和 56 年までは群馬県内に春期発生例はみられなかったが 昭和 56 年に 2 例, 57 年に 4 例， 58 年に 2 例がみられ るようになった。

昭和53年から58年12月までの群馬県内での患者発
生総数は110例で, その発生地区別分布は図 3 にみら れる如くで中之条町52例, 吾妻町 26 例, 高山村 17 例 と群馬県北部に集中しているが富士見村，宮城村・ 前橋市・大胡町へと拡大してきている。

図 3 群馬県内における恙虫病発生の地区別分布

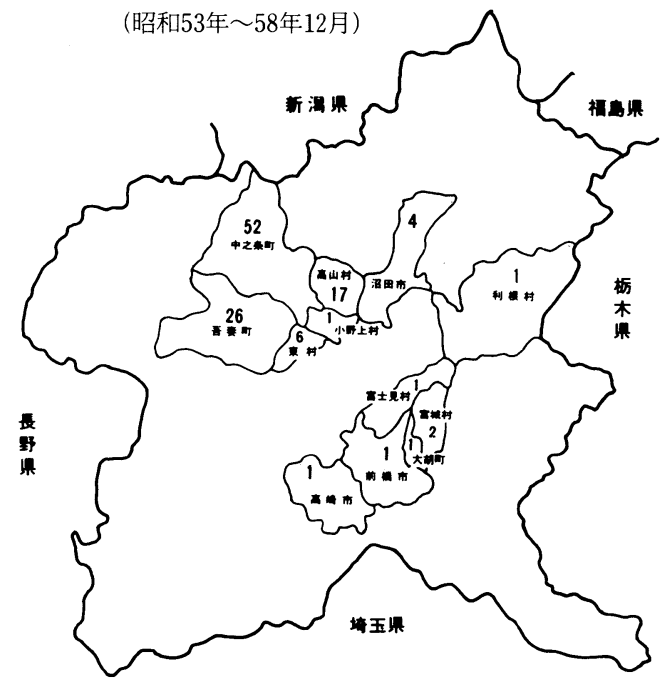

なお高崎市の 1 例は28才の男性で前橋日赤病院内 科へ昭和58年 8 月 2 日に入院して全治退院した例で あるが，福島のイナ川へ鮎釣りに行って発病したと 思われる例で感染場所は県外とみた方が適当と思わ れる。

県内での患者の年令分布は図 4 に示した.10才以

図 4 群馬県内恙虫病患者の年令分布と男女差

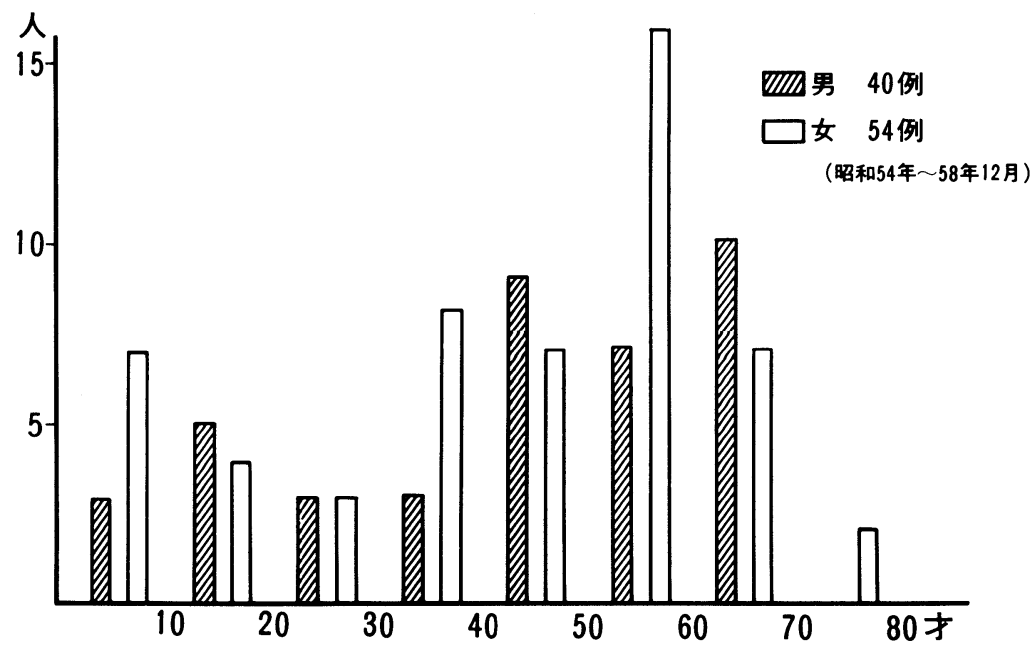


下にも10例がみられているが，40才代・50才代・60 才代に多く，女性が全体の $57.4 \%$ を占めている。吾 妻町・中之条町住民の抗体保有調査でも男性より女 性が高く，年齢別では 30 才代・20才代・40才代に高 い成績が得られている。

野鼠からリケツチアの検出も試みられているが, リケツチアの分離されているのはアカネズミで八夕 ネズミやモグラなどからは分離されず年間を通じて の陽性率は昭和 56 年の調查で東村 $26.7 \%$, 中之条町 $18.2 \%$ ，吾妻町 $5.6 \%$ などである ${ }^{4)}$.

野鼠から分離したツツガムシの幼虫はタテツツガ ムシ・フトツツガムシなど 4 属12種を認めているが アカツツガムシは認められていない.

またリケツチアのプロトタイプ分けでは Karp 株, Gillan株, あるいは両抗原陽性例もみられたが Kato 株はみられていない。

臨床的に発疹は全例に確認され, 刺し口もほとん どの例で発見されている。その部位は腋窩・胸部・ 腹部・腰部などの軀幹に多く慰部, 下腿などは比較 的少なかった。

$$
4 \text { 考案 }{ }^{5 \sim 8)}
$$

古来わが国をはじめ東洋諸国には恙虫病はかなり 広範に存在したようである。しかし吾々の知る限り では新潟・山形・秋田などの信濃川・阿賀野川・最
上川・雄物川流域などに限局した風土病とみられて いた。

明治初期から本邦で研究が開始され，本疾患の伝 播はダニであるアカツツガ虫幼虫に人が刺されて発 病することが知られたが，病原体が Rickettsia tsugamushi であることが知られたのは長与・田宮・三 田村により昭和5年 (1930年) に発見されている。

恙虫病りケツチヤは自己代謝系の一部を欠損する ため偏性細胞寄生性で人工培地での増殖が出来な い. Rickettsia を保有するツツガムシの幼虫に刺さ れると10～14日の潜伏期の後に頭痛・発熱・発疹・ リンパ節腫脹・刺口などの症状をもつ熱性発疹性疾 患となる。

病原リケツチア標準株としては Kato 株, Karp 株, Gillan 株の 3 株がある.

対症療法しか行えなかった時代の死亡率は 30〜 50\%と高率であったが，クロラムフエニコール (CM), テトラサイクリン (TC) の著効が知られると 死亡者はなくなって昭和 36 年を peak として昭和 40 年代には恙虫病は消滅したものと思われていた。 ころが昭和51年（1976年）頃から次第に本症発生の 届出が増加してきている。しかも表 2 にみられるよ うに，全国的に今迄発生したことのなかった静岡， 宮崎 ${ }^{9}$, 東京 (伊豆七島), 青森, 富山, 群馬, 山梨10), 福島, 山形, 大分, 鹿児島, 熊本 ${ }^{11}$, 長野県 ${ }^{12)}$ にも

表 2 県別の恙虫病患者発生状況

\begin{tabular}{|c|c|c|c|c|c|c|c|c|c|c|c|c|c|c|c|c|c|}
\hline 年 & 言菜 & 岩手 & 秋田 ${ }^{*}$ & 山形* & 楅悤 & 新渴 ${ }^{*}$ & 冨山 & \begin{tabular}{|l|} 
長魣 \\
\end{tabular} & 群馬 & 杲京 & \begin{tabular}{|l|} 
山梨 \\
\end{tabular} & 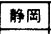 & 大分 & \begin{tabular}{|l|} 
熊本 \\
\end{tabular} & 宫峙 & 裹児亩 & 合到(例) \\
\hline 1960 & & & 33 & & & 16 & & & & & & 14 & & & 1 & & 64 \\
\hline 1961 & & & 35 & & & 24 & & & & & & 41 & & & & & 100 \\
\hline 1962 & & & 27 & & & 27 & & & & & & 14 & & & & & 68 \\
\hline 1963 & & & 9 & & & 11 & & & & & & 19 & & & 2 & & 41 \\
\hline 1964 & & & 10 & & & 3 & & & & 1 & & 5 & & & 4 & & 23 \\
\hline 1965 & & & 5 & & & 2 & & & & & & & & & & & 7 \\
\hline 1966 & & & 3 & & & 4 & & & & & & & & & & & 7 \\
\hline 1967 & & & 2 & & & 1 & & 1 & & & & & & & & & 4 \\
\hline 1968 & & & 0 & & & 1 & & & & & & & & & & & 1 \\
\hline 1969 & & & 2 & & & 1 & & & & & & & & & & & 3 \\
\hline 1970 & & & 2 & & & 1 & & & & & & 3 & & & & & 6 \\
\hline 1971 & 2 & & 2 & & & 3 & & & & & & 1 & & & 3 & & 11 \\
\hline 1972 & & & 0 & & & & & & & & & 2 & & & & & 7 \\
\hline 1973 & 1 & & 2 & & & 14 & & & & & & 2 & & & & & 6 \\
\hline 1974 & & & 2 & & & $2(1)$ & & & & 7 & & 0 & & & & & 11 \\
\hline 1975 & 2 & & 0 & & & $3(1)$ & & & & 9 & & & & & & & 14 \\
\hline 1976 & 2 & & $6(1)$ & & & $3(1)$ & 4 & & & 20 & & 5 & & & & & 40 \\
\hline 1977 & & & $12(1)$ & & & $8(1)$ & 5 & & & 13 & & 6 & & & 1 & & 67 \\
\hline 1978 & & & $13(5)$ & & 1 & $6(2)$ & 11 & & 18 & 6 & 2 & 18 & & & 1 & & 76 \\
\hline 1979 & & & $18(12)$ & & & $10(8)$ & 15 & & 24 & 18 & 2 & 10 & & & 10 & & 107 \\
\hline 1980 & 5 & & $35(32)$ & 1 & 1 & $10(8)$ & 19 & & 25 & 4 & 1 & 14 & 1 & & 41 & 81 & 238 \\
\hline 1981 & 3 & 1 & $18(18)$ & $5(5) \mid$ & 1 & $25(23)$ & 18 & 6 & 20 & 3 & 0 & $56^{* *}$ & 0 & 5 & 26 & 223 & 410 \\
\hline 1982 & 5 & 5 & $46(42)$ & $2(2)$ & & $39(39)$ & 11 & 3 & 19 & & & 19 & & & 29 & 247 & 425 \\
\hline
\end{tabular}

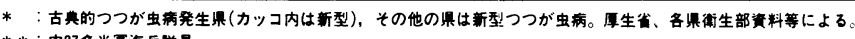

**: 内 37 名米更海兵胼员 
異常な経過の恙虫病と群馬県内発生状況

表 3 DIC の診断基準

I. 別表 1 に示す基礎疲患

$$
\text { あり }
$$$$
\text { なし }
$$

II. 別表 2,3 に示す臨床症状

1) 出血症状(法1)

$\begin{array}{ll}\text { あり } & 1 \\ \text { なし } & 0\end{array}$

2 ) 臓器症状

$$
\begin{aligned}
& \text { あり } \\
& \text { なし }
\end{aligned}
$$

III. 検查成績

1) 血清 FDP $(\mu \mathrm{g} / \mathrm{ml})$

$\begin{array}{lll}40 \leqq & & 3 \\ 20 \leqq & <40 & 2 \\ 10 \leqq & <20 & 1 \\ 10> & & 0\end{array}$

2) 血小板数 $\left(\times 10^{3} / \mu 1\right)$ (注1)

$\begin{array}{rll}50 \geqq & & 3 \\ 80 \geqq & >50 & 2 \\ 120 \geqq & >80 & 1 \\ 120 \leqq & & 0\end{array}$

$3)$ 血漿フィブリノーゲン $(\mathrm{mg} / \mathrm{dl})$

$\begin{array}{ll}100 \geqq & \\ 150 \geqq \\ 150<\end{array} \quad>100 \quad \begin{aligned} & 2 \\ & 1 \\ & 1 \text { r }\end{aligned}$

4) プロトロンビン時間（秒）(注2)

$\begin{array}{ll}20 \leqq \\ 15 \leqq \\ 15>\end{array} \quad<20 \quad \begin{aligned} & 2 \\ & \end{aligned}$

VI. 判 定
1) 7 点以上
DIC
6 点
DIC の疑い(注3)
5 点以下 DICの可能性少ない(注3)

2 ) 白血病その他註 1 に該当する疾患
4 点以上
DIC
3 点
DICの疑い(注3)
2 点以下 DICの可能性少ない(注3)

$\mathrm{V}$. 確定診断のための検査成績, 所見

1) 血漿アンチトロンピンIIIの減少

2) 血漿プラスミノゲンの減少

3 ）硫酸プロタミン試験またはエタノールゲル化試 験陽性ないしクリオフィブリノゲン検出

4 ) 血漿 $\alpha_{2}$ プラスミンインヒビターの減少

5 ）血漿フィブリノゲンが 3 日以内に $50 \%$ 以上減少

6 ）へパリン投与による臨床症状ならびに検查成績 の改善

7 ) フィブリン血栓の証明

VI. 註 1 : 白血病および類縁疾患, 再生不良性貧血, 抗 腫湯剂投与後など骨髄巨核球減少顕著で, 高度 の血小板減少をみる場合, 血小板および出血症 状の項は 0 とし, 判定はVI- 2 に従う

註 2 : プロトロンビン時間の正常值が 12 秒前後の時 とする。新生児は 20 秒未満を 0 点とし, 以上を 1 点とする.

註 3 : 確定診断のうち 2 項目以上を満たせば DIC と判定する

VII. 除外規定

顕著な肝機能障害を伴うもの, 尿蛋白量の多いネフ ローゼ症候群には,この診断基準を適用しない

別表 1

\section{A. 感染症}

1.グラム陰性菌感染症

2. 重症グラム陽性菌感染症

3. 重症ウイルス感染症

B.ショック

C. 悪性腫瘍

1. 白血病

2. 癌・肉腫の浸潤および播種性転移

D. 産科的疾患

胎盤早期剝離, 羊水栓塞, 死胎稽留, 胞状奇胎, 姓娠中毒

E. 血管内溶血
F. 組織損傷

1. 大手術後 (肺, 前立腺, 膵, 副腎の手術, 長時間 にわたる体外循環)

2 . 広範囲の外傷

3 . 広範囲の熱傷

G. 血管病変

1. Kasabach-Merritt 症候群

2 , 心臟瘤, 大動脈瘤

3. 血栓性血小板減少性紫斑病, 溶血性尿毒症症候群

4. 膠原病

H. その他

重症呼吸窮迫症候群, 移植臓器の拒絶反応, 毒蛇 咬傷, 電撃性紫斑病など 
別表 2
A. 紫斑, 注射部位上り異常出血, 下血, 性器出血
B. 血尿, 創傷面よりの異常出血, 歯肉出血, 鼻出血, 頭蓋内出血, 血痰
C. その他の出血
D. 基碟疾患と直結する出血は 0 点とする

別表 3
A. 無尿, 乏尿, 呼吸困難, ショック, 黄疸, 精神神経 症状, 下痢
B. 静脈血栓，動脈血栓，四肢末端壊死
C. その他 DIC に基づくと思われる症状
D. 基礎疾患と直結する症状は 0 点とする

発生してきている，そして昭和 52 年に 1 例，昭和 54 年に 2 例, 昭和 55 年に 4 例と死亡例が報告されてい る ${ }^{13)}$.これらの死亡例では DIC の関係でみている報 告が多(214)15).

恙虫病患者で血液凝固性が著しく低下していると いう記載は Baelz も Kawakami ${ }^{16)}$ (1879 年) の最初 の報告にもみられるが，その後も凝固性の障害と出 血素因を本症の重要な特徴にあげている報告 ${ }^{17 \sim 19)}$ も多い。

臨床上 DIC と診断するための検查法とその判定 は各研究者で異なるが真木 ${ }^{20)}$ の記載では(1)血小板 数 15 万以下, (2) FDP $10 \mu \mathrm{g} / \mathrm{ml}$ 以上, (3)フィブリノー ゲン $150 \mathrm{mg} / \mathrm{dl}$ 以下，(4) prothrombin 時間延長，(5) 部分 thromboplastin 時間延長を必要条件として LDH の増加などをかげている. 今回の著者らの治 験例はこの各頃目を満していて DIC と診断される. しかしながら最近では ${ }^{21} \mathrm{DIC}$ の診断基準がさらに厳 密になってきている，基礎疾患の存在や臨床症状に
も依存するので,これらと検査成績から DIC を決定 しょうと試みられている。すすおわち，(1)基礎疾患の 有無，(2)臨床症状としての出血症状の有無，(3)検査 成績として1) 血清 FDP，2）血小板数，3）血漿フィブ リノーゲン，4)プロトロンビン時間など，さらに各 頃目の程度に応じて $0 \sim 3$ 点と採点してその合計に よる総合点数から診断しょうとの方法が提案されて いる ${ }^{22)}$.ここには表 3 亿前川教授らの DIC の診断基 準23)を掲げた。これに従えば本例は DIC の疑い程 度となる.DICの確実な診断のためには結構と思わ れるが救命する立場としての治療のためには疑いの 段階で治療が開始される必要がある。なお，表 3 の 感染症の項には, 最近の恙虫病による DIC の報告例 を加味して考える必要があるので重症感染症とした らと思われる。

昭和 23 年秋，富士山麓で演習中の米国兵士の間に 多数の本症がみられた頃から，春・秋に発生する原 因不明の発疹を併う熱性疾患の多くが恙虫病である

図 5 古典的ならびに新型恙虫病の発生状況

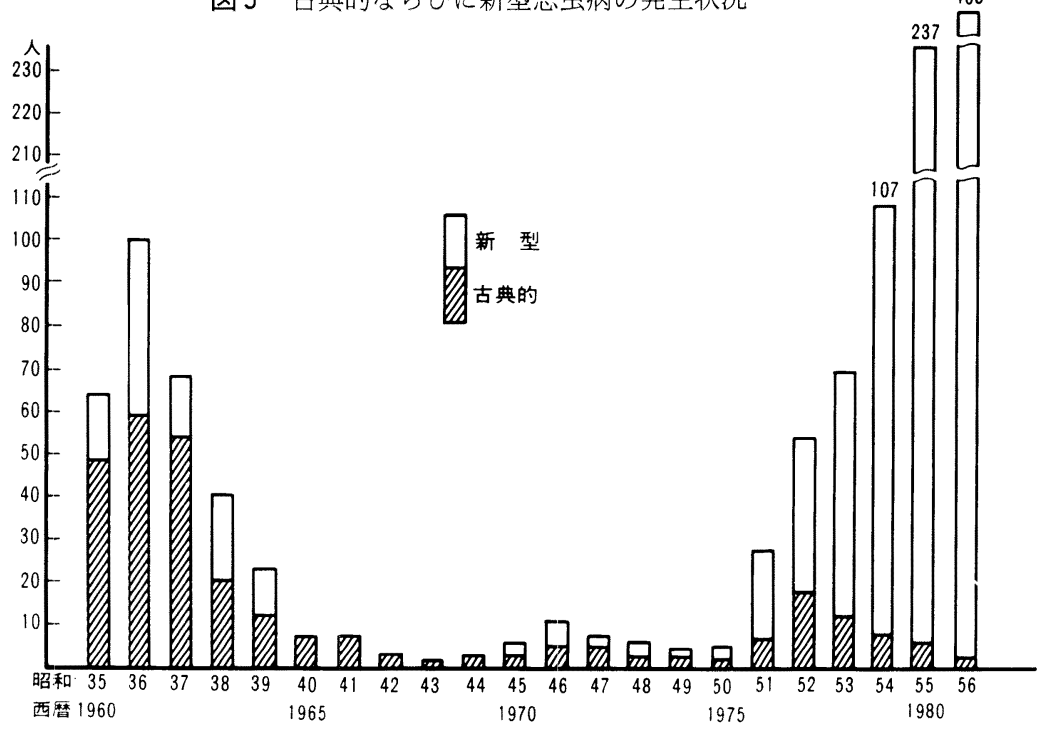


ことが知られていた。

そして従来の恙虫病と病態や発生時期が異なる恙 虫病であることがわかってきている。 そこで現在で は従来のものを古典的恙虫病, 最近のものを新型恙 虫病とよんで区別している。昭和51年以降では図 5 に示されるように新型恙虫病の発生頻度が圧倒的に 多くなってきていることがわかる.

古典的恙虫病と新型恙虫病の疫学や臨床症状など での比較は斎藤ら7)によって表 4 のようにまとめら れている.

表 4 古典的恙虫病と新型恙虫病の比較

\begin{tabular}{|c|c|c|c|}
\hline & 古典的恙虫病 & 新型恙虫型 \\
\hline \multicolumn{2}{|c|}{ 媒介動物 } & アカツツガムシ & フトゲツツガムシ \\
\hline \multicolumn{2}{|c|}{ 発症季節 } & 夏から秋 & 春・秋 \\
\hline \multicolumn{2}{|l|}{ 発生地 } & 洪水地帯 & 原野 - 山林地帯 \\
\hline \multicolumn{2}{|l|}{ 潜伏期 } & \multicolumn{2}{|c|}{$7 \sim 14$ 日 } \\
\hline \multicolumn{2}{|c|}{ 熱型（Max） } & 䅨留熱 $\left(42^{\circ} \mathrm{C}\right)$ & 弛張熱 $\left(40^{\circ} \mathrm{C}\right)$ \\
\hline \multicolumn{2}{|l|}{ 刺口 } & 必 発 & 時に欠如 \\
\hline \multicolumn{2}{|c|}{ 局所リンパ穊の腫脹 } & 必 発 & 時に欠如 \\
\hline \multirow{3}{*}{ 発 疹 } & 頻 & 半数にあり & 稀に欠如 \\
\hline & 期 & $3 \sim 7$ 日 & $3 \sim 14$ 日 \\
\hline & 出 & 稀にあり & な し \\
\hline \multicolumn{2}{|c|}{ 頭痛、食思不振 } & 必 発 & 時に欠如 \\
\hline \multicolumn{2}{|l|}{ 肺 资 } & 時にあり $(20 \%)$ & な し \\
\hline \multicolumn{2}{|l|}{ 脾 腫 } & 半数にあり $(46 \%)$ & な し \\
\hline \multicolumn{2}{|l|}{ 肝 腫 } & 時にあり $(35 \%)$ & 時にあり \\
\hline \multicolumn{2}{|c|}{ 中枢神経系の症状 } & 時にあり & 稀にあり \\
\hline \multicolumn{2}{|c|}{ 白血球数 } & 著明に減少 & 減少しないもの多し \\
\hline \multicolumn{2}{|c|}{ 抗リッチア抗体価 } & 陽 性 & 陽 性 \\
\hline
\end{tabular}

一方，恙虫病の再燃的発生に関して色々と考察が 行われている。戦後大量に使用されていた害虫駆除 剤である DDT, BHC が昭和 46 年に使用が禁止され たことに関係があるとするもの，あるいは須藤6も も 指摘するように恙虫病に著効を示す $\mathrm{TC}, \mathrm{CM}$ の生 産量の減少, 合成 $\mathrm{PC}, \mathrm{CE}$ 系抗生物質の生産量が増 加して $\beta$-ラクタム系やアミノグリシッド系の抗生 物質使用量が増加した時期に一致して, これらの薬 凨に無効な恙虫病が増加しているともみられてい る.図 6 は我が国の恙虫病発生数の推移と国立予防 衛生研究所の年次毎の各種抗生物質の国家検定数量 の推移を示すもので参考となる興味ある資料となっ ている.
図6 年次別恙虫病発生数推移（1958～1980, 全国)
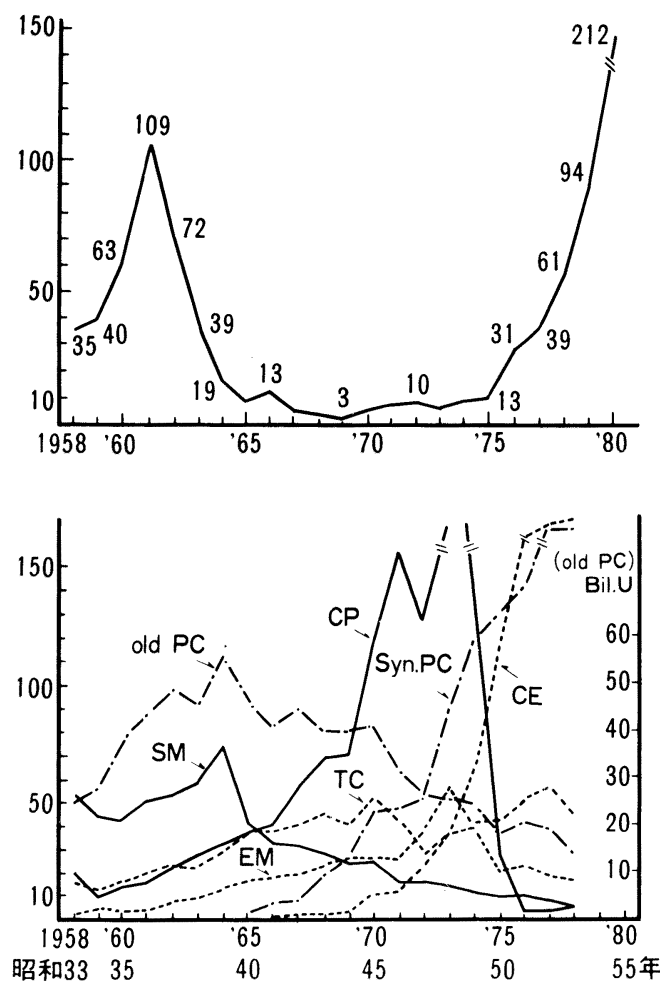

5 結

語

原因不明のまま急性腹膜炎として開腹した 33 才の 女性で, リムルス試験陽性, DIC と診断された。最 初敗血症を疑って治療を開始したが, 右下腿の刺口 と思われる小潰瘍を発見して血液検査でも恙虫病が 確認された。異常な経過をとった恙虫病の 1 治験例 を報告するとともに群馬県内での発生状況や本症に 関しての考察を行った。

\section{参 考 文 献}

1）氏家淳雄, 小山 孝, 阿久沢孝文他：群馬県 に扮ける恙虫病. 群馬県衛生公害研究所年報11 号, 41 51，1979.

2）氏家淳雄, 小山 孝, 兽我健一, 他：群馬県 に打ける恙虫病 (II). 同上12号, 29〜41, 1980.

3）小山 孝, 阿久沢孝文, 曽我健一他: 群馬県 における恙虫病(III). 同上, 13号, 37〜44, 1981

4）小山 孝, 阿久沢孝之, 大谷仁已他：群馬県 に打ける恙虫病(IV). 同上, 14号, 25 30, 1982. 
5）川村明義：つつが虫病流行の変遷。日本細菌 学雑誌, 38 (特) : 42〜 48, 1983.

6）須藤恒久：恙虫病の現状とその迅速診断法. 日本医事新報，3034：43～49，1982。

7）斉藤秀沓, 関川弘雄, 監物 実: 新型恙虫病 の臨床. 日本医事新報，3007：23～30，1981.

8) 大鶴正満： 最近の特に新型恙虫病の発生をめ ぐって. 日本臨床, $42: 725 \sim 739,1984$.

9）橘 宣祥, 楠根英司, 横川 勉他: 宮崎地方 の恙虫病. 感染症学雑誌, $56: 655,1982$.

10）金丸佳郎, 梶原徳昭, 佐藤 譲：山梨県にお ける恙虫病の疫学調查. 山梨県衛生公害研年報, $25: 48 \sim 50,1981$.

11）甲木和子, 坂井末男, 道家 直他：熊本県に おけるツツガムシ病について。熊本県衛生公害 研報, $11: 18 \sim 19,1981$.

12）斉木 実, 芝本利重, 百瀬邦夫他：長野県下 の恙虫病について. 信州医誌, 30：245～252, 1982.

13）鈴木俊夫：最近の恙虫病発生状況. 総合臨床, $30: 2814,1981$.

14）鈴木俊夫, 関川弘雄：血管内凝固症候群を併 発した恙虫病の4 例. 感染医学雑誌, 55：
$642 \sim 648,1981$.

15）赤井裕輝，伊藤政志，進藤多妃子，他：血管 内凝固症候群の所見を呈した恙虫病の一剖検 例. 日内会誌, $71: 59 \sim 64,1982$.

16) Baelz. und. Kawakami. S. : Das Japanische Fluss oder Ueberschwemnungsfieber, eine acute Infektionskrankt. Archiv. pathol, Anat, physiol, klin. Med, LXXIII : 373 420, 1879.

17) 田中敬助：日本洪水熱病原研究. 東京医学会 誌, $22 ： 1069 \sim 1072 ， 1892$.

18）林 直助：恙虫病の剖検並びに組織学的研 究. 北越医会誌, $165 ： 115 \sim 158,1908$.

19) Kawamura. R. : Studies on tsutsugamushi disease. Med, Bull, College Med., Univ, Cicinnati. 1926. pp. 229.

20）真木正博：血管内疑固症候群. 金原出版, 東 京, 1978. 231頁.

21）小宮正文編： 汎発性血管内血液凝固症 I IV. （調査研究班業績報告1978～1981）

22）松田 保： DIC. 中外医学社. 東京， 1979 .

23）前川 正：DICの診断基準. 診断と治療, 70 : $654 \sim 658,1982$. 
A CASE OF TSUTSUGAMUSHI DISEASE SHOWED THE SEVERE ABDOMINAL PAIN AND THE DISSEMINATED INTRAVASCULAR COAGULATION (DIC).

A STUDY ABOUT A STATE OF OCCURRENCE OF TSUTSUGAMUSHI DISEASE IN GUNMA PREFECTURE.

SHOICHI AIBA, HIDEO SHIOZAKI, HIROSHI MATSUMOTO, KATSUMASA UEHARA, TOSHIYUKI HIRAI, MASAYA NAKAMURA, KEI NAKAMURA, TAMIYUKI OBAYASHI, SUSUMU ISHIKAWA.

Department of Sumgery, Maebathi Red Cross Hospital.

ATSUO UZIIE, TAKASHI KOYAMA, TAKAHUMI AKUZAWA.

Gunma Institute of Public Health.

A 33-years old female was referred to our hospital with the diagnosis of acute peritonitis, unknown origin.

Hematological date showed the leucocytosis with neutrophilia, the slight decrease in platelet count $\left(10 \times 10^{4} / \mathrm{mm}^{3}\right)$, the severe decrease of serum fibrinogen $(89 \mathrm{mg} / \mathrm{dl})$, and the moderate increase in serum FDP $(10 \mu \mathrm{g} / \mathrm{dl})$, bleeding time (9min.), coagulating time (15min.), the culture of the blood resulted in no growth of bacteria, but Limulus test was positive.

Our diagnosis is sepsis at the beginning, but we found small ulcer covered black crust at her right leg, and established Tsutsugamshi disease by serological test.

The patient was completely recovered by the therapy with tetracycline, but this clinical course was abnormal, so we reported this case, and studied about a state of occurrence of Tsutsugamushi disease in Gunma prefecture, and investigated about new type of Tsutsugamushi disease in Japan.

Key words: New type of Tsutsugamushi disease, DIC. 